\title{
Stimulated by Retinoic Acid Gene 8 Protein
}

National Cancer Institute

\section{Source}

National Cancer Institute. Stimulated by Retinoic Acid Gene 8 Protein. NCI Thesaurus.

Code C104905.

Stimulated by retinoic acid gene 8 protein $(330 \mathrm{aa}, \sim 37 \mathrm{kDa}$ ) is encoded by the human

STRA8 gene. This protein may be involved in spermatogenesis. 